\title{
Perbedaan Pola Konsumsi Ikan Laut dan Daging terhadap Kejadian Hipertensi pada Masyarakat
}

\author{
${ }^{1}$ Risha P. Rokot \\ ${ }^{2}$ Linda W. A. Rotty \\ ${ }^{3}$ Emma Sy. Moeis
}

\author{
${ }^{1}$ Program Studi Pendidikan Dokter Fakultas Kedokteran Universitas Sam Ratulangi Manado \\ ${ }^{2}$ Bagian Ilmu Penyakit Dalam Fakultas Kedokteran Universitas Sam Ratulangi Manado \\ Email: priscillarissharokot@gmail.com
}

\begin{abstract}
Hypertension is one of the most influential risk factors for the incidence of heart and blood vessel disease. Poly-unsaturated fatty acid (PUFA) $\omega-3$ and $\omega-6$ fatty acids proven to be cardioprotective, which is contained in marine fish, namely EPA and DHA. Fish oil is useful to change $\omega-3$ to $\omega-6$ to help lower blood pressure and various risks of myocardial infarction. The very high content of purines and bad fats in meat can cause increased cholesterol levels in the blood. This study was aimed to determine the differences between marine fish and meat consumption to the incidence of hypertension in people of rural area (Manembo-nembo) and of urban area (Manado city). Samples were people in Manembo-nembo Bitung and employees of Prof. Dr. R. D. Kandou Hospital Manado aged 30-50 years old. The criteria of blood pressure were based on the US Join National Committee (JNC) 7. Consumption of marine fish and meat was categorized as high, moderate, and poor. Questionnaires were filled by all subjects. Blood pressure was measured by using aneroid sphygmomanometer. Data were analyzed by using Man-Whitney test. The rate of hypertension in rural area for the blood pressure value was $-2.121(P=0.034)<0.05$ while in urban area, the blood pressure value was $2.859(P=0.004)<0.05$. Conclusion: There were significant differences in systolic and diastolic blood pressure between people in marine fish consumption area (rural area) and in meat consumption area (urban area).
\end{abstract}

Keywords: hypertension, consumption of sea fish and meat

\begin{abstract}
Abstrak: Hipertensi merupakan salah satu faktor risiko yang paling berpengaruh terhadap kejadian penyakit jantung dan pembuluh darah. Asam lemak poly-unsaturated fatty acid (PUFA) $\omega-3$ dan $\omega-6$ yang terbukti kardioprotektif, terkandung dalam ikan laut yaitu EPA dan DHA. Minyak ikan berguna untuk mengubah secara cepat $\omega-3$ menjadi $\omega-6$ untuk membantu menurunkan tekanan darah dan berbagai risiko infark miokard. Kandungan lemak yang tinggi dalam daging dapat menyebabkan meningkatnya kadar kolesterol dalam darah. Selain itu, Penelitian ini bertujuan untuk mengetahui perbedaan pola konsumsi ikan laut dan daging terhadap kejadian hipertensi pada masyarakat di daerah rural/pedesaan (Manembo-nembo), dan di daerah urban/perkotaan (kota Manado). Sampel penelitian ialah masyarakat di Kelurahan Manembo-nembo Bawah Kota Bitung dan Pegawai di RSUP Prof. Dr. R. D. Kandou Kota Manado yang berusia 30-50 tahun. Kriteria tekanan darah pada penelitian ini berdasarkan US Join National Committee (JNC) 7. Konsumsi ikan laut dan daging dibagi atas kurang, sedang, dan banyak. Pengisian kuesioner oleh subyek penelitian, dan pengukuran tekanan darah menggunakan sfigmomanometer aneroid. Analisis data untuk mengetahui perbedaan pola konsumsi ikan laut dan daging terhadap tekanan darah, menggunakan uji Mann-Whitney. Hasil penelitian mendapatkan angka hipertensi di daerah rural untuk nilai tekanan darah ialah $-2,121(P=0,034)<0,05$ sedangkan di daerah urban nilai tekanan darah 2,859 $(P=0,004)<0,05$. Simpulan: Terdapat perbedaan bermakna dalam tekanan darah sistol dan diastol pada masyarakat pengonsumsi ikan laut (daerah rural) dan yang pengonsumsi daging (daerah urban).
\end{abstract}

Kata kunci: hipertensi, konsumsi ikan laut dan daging 
Hipertensi adalah suatu keadaan dimana terjadi peningkatan tekanan darah diatas ambang batas normal yaitu $120 / 80 \mathrm{mmHg}{ }^{1}$ Transisi epidemiologi di Indonesia menyebabkan terjadinya pergeseran pola penyakit, yaitu terjadi peningkatan penyakit kronis degeneratif. Salah satu penyakit kronik yang berkaitan dengan faktor tersebut ialah hipertensi. Hipertensi adalah peningkatan tekanan darah sistolik $140 \mathrm{~mm}$ $\mathrm{Hg}$ dan tekanan diastolik $90 \mathrm{~mm} \mathrm{Hg}$. Prevalensi hipertensi di Indonesia cukup tinggi. Selain itu, akibat yang ditimbulkannya menjadi masalah kesehatan masyarakat. Hipertensi merupakan salah satu faktor risiko yang paling berpengaruh terhadap kejadian penyakit jantung dan pembuluh darah. $^{2}$

Prevalensi hipertensi di Indonesia berdasarkan hasil pengukuran menurut usia $>18$ tahun sebesar 25,8\%. Prevalensi hipertensi di Indonesia yang diperoleh melalui kuesioner terdiagnosis tenaga kesehatan atau sedang minum obat sebesar $9,5 \%$. Terdapat $0,1 \%$ yang minum obat sendiri. Responden yang mempunyai tekanan darah normal tetapi sedang minum obat hipertensi sebesar $0,7 \%$. Jadi, prevalensi hipertensi di Indonesia sebesar 26,5\%. Prevalensi hipertensi di Sulawesi Utara yang diperoleh melalui kuesioner terdiagnosis tenaga kesehatan ialah $15 \%$, sedang minum obat $15,2 \%$ dan melalui pengukuran ialah $27,1 \%{ }^{3}$

Hipertensi dapat terjadi karena banyak faktor, baik faktor yang dapat diubah maupun tidak. Faktor yang tidak dapat diubah ialah ras, usia, riwayat keluarga, dan jenis kelamin. ${ }^{4}$ Hipertensi dapat terjadi karena makanan, khususnya konsumsi makanan berlemak dan tinggi garam. Selain itu, gaya hidup seperti merokok dan kuranng berolahraga juga berhubungan dengan kejadian hipertensi. ${ }^{5}$

Ikan adalah sumber protein yang baik dan rendah lemak saturasinya. Ikan, khususnya spesies yang mengandung banyak lemak, seperti sardin, tuna, dan salmon, mengandung dua jenis asam lemak $\omega-3$ yang terbukti kardioprotektif,yaitu EPA dan DHA. ${ }^{6}$ Minyak ikan berguna untuk mengubah secara cepat $\omega-3$ menjadi $\omega-6$ untuk membantu menurunkan tekanan darah dan berbagai risiko infark miokard. ${ }^{7}$

Seiring berubahnya gaya hidup di perkotaan mengikuti era globalisasi, kasus hipertensi terus meningkat. Gaya hidup gemar makanan fast food yang kaya lemak, asin, dan malas berolahraga, ikut berperan dalam menambah jumlah pasien hipertensi. Gaya hidup yang tidak sehat pada masyarakat Minahasa saat ini terlihat pada pola makan yang sering mengonsumsi makanan daging yang mengandung tinggi lemak dan garam. Jenis makanan daging yang biasa dikonsumsi masyarakat suku Minahasa yakni daging babi.

Dalam proses metabolisme tubuh, garam yang dikonsumsi sebagian besar akan diserap oleh usus dan dibuang kembali oleh ginjal melalui urin. Jika jumlah garam yang dikonsumsi melebihi kapasitas ginjal untuk mengeluarkannya kembali, maka kadar natrium dalam darah akan meningkat, dan untuk menormalkannya kembali cairan intrasel harus ditarik keluar sehingga volum cairan ekstrasel meningkat. Meningkatbya volum cairan ekstrasel tersebut menyebabkan meningkatnya volum darah, sehingga berdampak pada terjadinya hipertensi. ${ }^{8}$

Kecamatan Matuari Kota Bitung terbagi atas 3 kelurahan yakni: Kelurahan Manembo-nembo bawah, Manembo-nembo tengah, dan Manembo-nembo atas. Wilayahnya merupakan pesisir pantai. Penduduknya sebagian besar ialah nelayan, Masyarakat Manembo-nembo terkenal dengan produski lautnya yang cukup tinggi, Hasil laut yang diperoleh selain untuk memenuhi kebutuhan rumah sebagai lauk pauk, juga sebagai mata pencarian bagi masyarakat. Berbeda halnya dengan masyarakat Kota Manado yang lebih dominan mengonsumsi daging (makanan Minahasa) Mayoritas masyarakat Kota Manado lebih sering berbelanja makanan di luar rumah karena kesibukan pekerjaan yang sebagian besar ialah pekerja kantoran.

\section{METODE PENELITIAN}

Jenis penelitian ini ialah observasional 
analitik dengan desain potong lintang. Penelitian ini dilakukan pada bulan Oktober hingga bulan November 2016 bertempat di desa Manembo-nembo Kota Bitung dan RSUP Prof. Dr. R. D. Kandou Kota Manado.

Sampel penelitian ialah masyarakat usia 30-50 tahun. Digunakan metode proportional sampling untuk mengambil sampel. Sampel terdiri atas dua kelompok dibagi atas 30 subjek pengonsumsi ikan laut pada masyarakat di Manembo-nembo Bawah Kota Bitung dan 30 subjek pengonsumsi daging pada masyarakat/ pegawai di RSUP Prof. Dr. R. D. Kandou Manado. Yang termasuk dalam kriteria eksklusi ialah individu dengan riwayat penyakit ginjal, penyakit gagal jantung, dan konsumsi obat anti hipertensi. Variabel bebas ialah makanan laut dan daging sedangkan variabel terikat ialah tekanan darah.

Analisis data untuk melihat perbedaan tekanan darah di dua lokasi berbeda yakni daerah rural (pedesaan) dan daerah urban (perkotaan) menggunakan uji beda rerata sampel independen yaitu Uji t Independen jika data terdistribusi normal dan uji ManWhitney jika data tidak terdistribusi normal.

Konsumsi ikan laut dan daging dapat digambarkan lewat kuesioner dan digolongkan dalam tingkatam kurang, sedang, dan banyak. Dalam penelitian ini, dikatakan konsumsi ikan laut dan daging kurang bila mengkonsumsi 1-3x ikan laut dan daging dalam sebulan; Sedang, bila mengonsumsi $1-4 \mathrm{x}$ sajian porsi dalam seminggu; dan Banyak, bila mengonsumsi lebih dari 4-5 sajian porsi dalam seminggu.

Tekanan darah, diukur dengan menggunakan sphygnomanometer dan digolongkan dalam beberapa tingkatan: Normal: tekanan darah sistolik (TDS) $<120 \mathrm{mmHg}$ dan tekanan darah doastolik (TDD) $<80$ mm Hg; Pre-hipertensi: TDS 120-139 mm $\mathrm{Hg}$ dan atau TDD 80-89 $\mathrm{mm} \mathrm{Hg}$; Hipertensi stage 1: TDS 140-159 mm Hg dan atau TDD 90-99 $\mathrm{mm} \mathrm{Hg}$; Hipertensi stage 2: TDS >160 mm Hg dan atau TDD $\geq$ $100 \mathrm{mmHg}$.

\section{HASIL PENELITIAN}

Karakteristik dasar subyek penelitian terdiri atas usia, jenis kelamin, riwayat hipertensi, frekuensi minum obat hipertensi, frekuensi minum alkohol, merokok, frekuensi makan ikan laut, frekuensi makan daging, IMT, dan klasifikasi tekanan darah. Analisis univariat dalam penelitian ini mencakup jenis variabel yang diteliti yakni makan ikan laut, makan daging, dan kejadian hipertensi.

Gambar 1 memperlihatkan bahwa sebagian besar subyek mempunyai frekuensi makan ikan laut dengan kategori sedang berjumlah 31 orang $(51,7 \%)$, makan ikan dengan kategori banyak berjumlah 28 orang $(46,7 \%)$, dan yang paling sedikit makan ikan laut dengan kategori kurang berjumlah 1 orang $(1,7 \%)$.

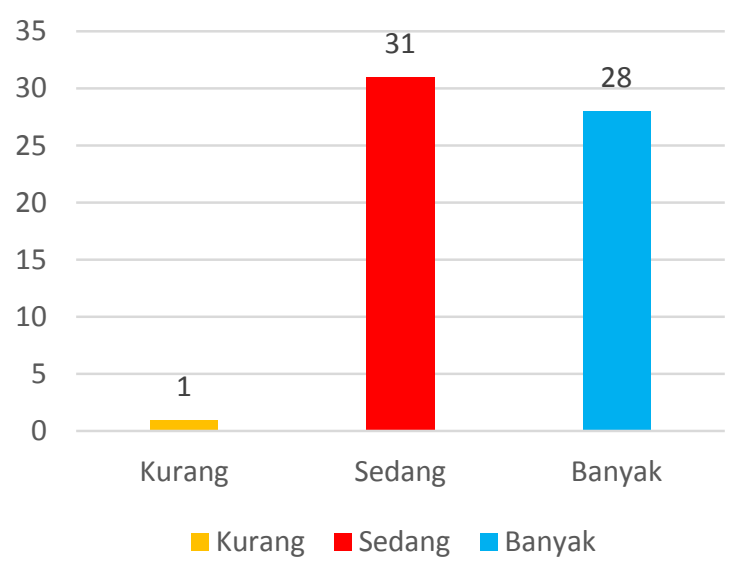

Gambar 1. Karakteristik makan ikan laut subyek penelitian

Gambar 2 memperlihatkan bahwa sebagian besar subyek mempunyai frekuensi makan daging dengan kategori kurang berjumlah 25 orang $(41,7 \%)$, makan daging dengan kategori sedang berjumlah 19 orang $(31,7 \%)$, dan yang paling sedikit makan daging dengan kategori banyak berjumlah 16 orang $(26,7 \%)$.

Gambar 3 memperlihatkan bahwa sebagian besar subyek mempunyai tekanan darah dengan kategori normal berjumlah 39 orang (65\%), tekanan darah dengan kategori pre-hipertensi berjumlah 13 orang $(21,7 \%)$, tekanan darah dengan kategori 
hipertensi stgae I berjumlah 7 orang $(11,7 \%)$, dan tekanan darah dengan kategori hipertensi stage II berjumlah 1 orang $(1,7 \%)$

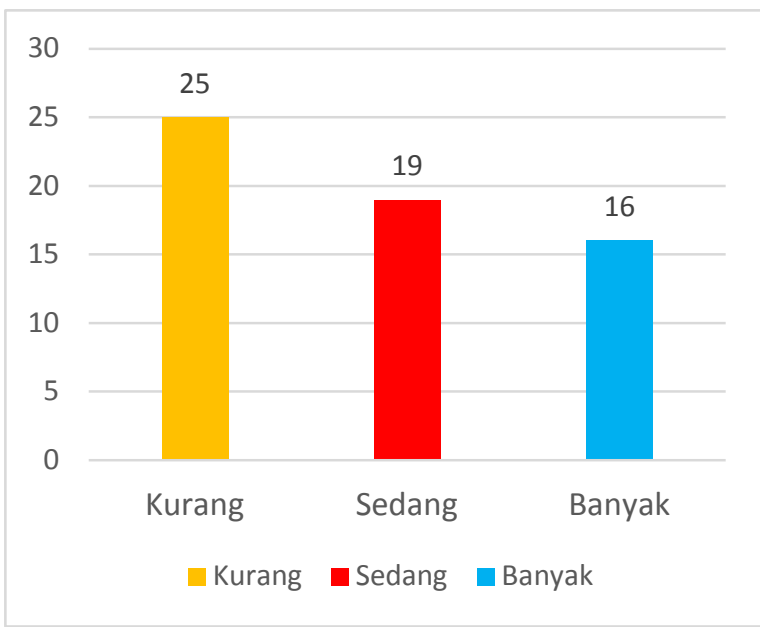

Gambar 2. Karakteristik makan daging subyek penelitian

Tabel 1 menjelaskan tentang data deskriptif nilai TDS dan TDD. Di daerah rural (pedesaan), rerata (mean) TDS ialah $118,66 \mathrm{mmHg}$, nilai terendah (minimum) $110,0 \mathrm{mmHg}$, nilai tertinggi (maksimum) $165 \mathrm{mmHg}$ dan simpangan baku (standar deviation) 12,92. Di daerah urban (perkotaan), rerata TDS ialah $123,50 \mathrm{mmHg}$, nilai terendah $110,0 \mathrm{mmHg}$, nilai tertinggi $145 \mathrm{mmHg}$ dan simpangan baku 11,07. Di daerah rural, rerata TDD ialah 76,16 $\mathrm{mmHg}$, nilai terendah $65,0 \mathrm{mmHg}$, nilai tertinggi $95 \mathrm{mmHg}$, dan simpangan baku 7,72. Di daerah urban, rerata TDD ialah $80,36 \mathrm{mmHg}$, nilai terendah $70,0 \mathrm{mmHg}$, nilai tertinggi $110 \mathrm{mmHg}$, dan simpangan baku 10,22.

Berdasarkan data di atas dapat diketahui bahwa tekanan darah baik sistol dan diastol di daerah urban (perkotaan)

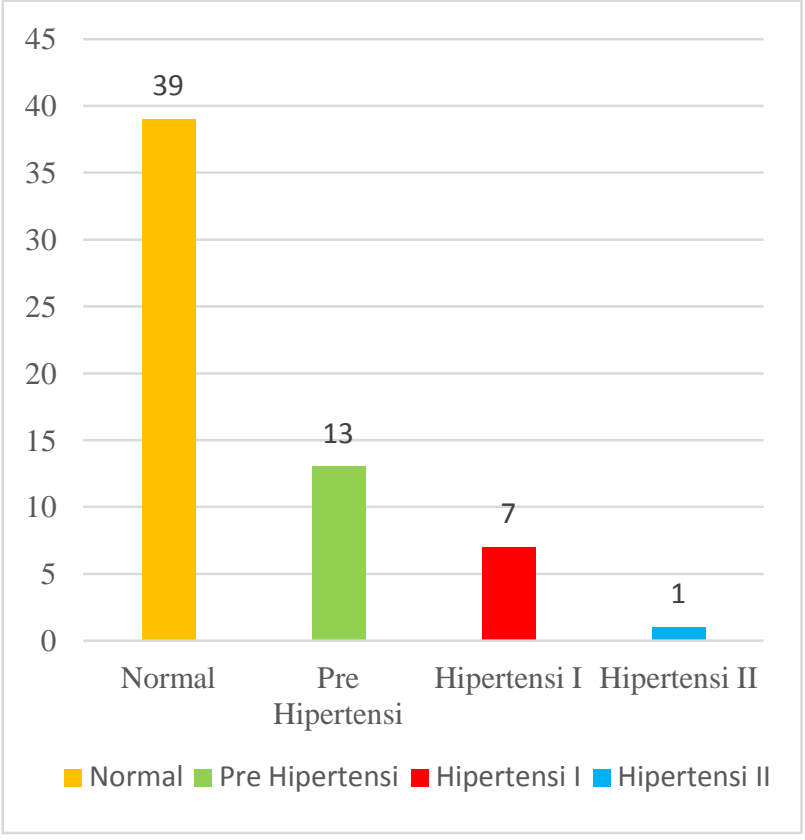

Gambar 3. Karakteristik tekanan darah subyek penelitian

lebih tinggi dibandingkan dengan di daerah rural (pedesaan). Pada daerah rural, rerata TDS ialah 118,66 mmHg, sedangkan pada daerah urban lebih tinggi yakni 123,50 $\mathrm{mmHg}$. Pada daerah rural, rerata TDD ialah $76,16 \mathrm{mmHg}$, sedangkan pada daerah urban lebih tinggi yakni $80,36 \mathrm{mmHg}$

Analisis bivariat dalam penelitian ini ialah melihat perbedaan tekanan darah di daerah rural (pedesaan) yang sebagian besar penduduknya makan ikan laut dan di daerah urban (perkotaan) yang sebagian besar penduduknya makan daging. Berdasarkan hasil uji normalitas data didapatkan bahwa sebagian data tidak terdistribusi secara normal $(P<0,05)$, sehingga uji yang dilakukan untuk perbedaan tekanan darah di daerah rural dan urban ialah uji nonparametrik Mann-Whitney.

Tabel 1. Data deskriptif tekanan darah daerah rural dan urban

\begin{tabular}{|c|c|c|c|c|c|}
\hline \multicolumn{2}{|c|}{ Data } & Mean & Minimum & Maximum & SD \\
\hline \multirow{2}{*}{ TDS } & Rural & 118,66 & 110,0 & 165,0 & 12,92 \\
\hline & Urban & 123,50 & 110,0 & 145,0 & 11,07 \\
\hline \multirow{2}{*}{ TDD } & Rural & 76,16 & 65,0 & 95,0 & 7,72 \\
\hline & Urban & 80,36 & 70,0 & 110,0 & 10,22 \\
\hline
\end{tabular}


Hasil uji statistik menggunakan uji Mann-Whitney menunjukkan bahwa nilai $Z_{\text {hitung }}$ TDS ialah $-2,121$ dan nilai signifikansi $P=0,034<0,05$. Nilai $Z_{\text {hitung }}$ TDD ialah $-2,859$ dan nilai signifikansi $P=0,004<0,05$. Hal ini menunjukkan bahwa terdapat perbedaan bermakna antara TDS dan TDD di daerah rural (daerah pedesaan) yang penduduknya lebih banyak makan ikan laut dengan tekanan darah di daerah urban (daerah perkotaan) yang penduduknya lebih banyak makan daging.

\section{BAHASAN}

Subyek penelitian ini berkisar antara 30-50 tahun. Sebagian besar berada pada golongan umur 40-50 tahun dengan jumlah 32 orang $(53,3 \%)$. Hasil penelitian Puspitasari et $\mathrm{al}^{9}$ menyatakan bahwa usia mempunyai hubungan dengan kejadian hipertensi, bahkan merupakan faktor paling dominan dalam kejadian hipertensi. Demikian juga dengan penelitian Hermida $^{10}$ yang menyatakan bahwa usia berpengaruh terhadap tekanan darah pada pasien hipertensi. Hal ini sesuai dengan teori yang menyatakan bahwa setelah usia 45 tahun, dinding arteri akan mengalami penebalan karena adanya penumpukan zat kolagen pada lapisan otot sehingga pembuluh darah akan berangsur-angsur menyempit dan menjadi kaku. ${ }^{11}$

Perbandingan jenis kelamin laki-laki dan perempuan dalam penelitian ini ialah sama yakni masing-masing sebanyak 50\%. Dalam kasus hipertensi pada lansia, Pradetyawan $^{11}$ mengemukakan bahwa jenis kelamin berhubungan dengan kejadian hipertensi, dalam hal ini jenis kelamin perempuan. Berdasarkan riwayat hipertensi diperoleh data bahwa sebagian besar tidak mempunyai riwayat hipertensi $(63,3 \%)$. Riwayat keluarga positif hipertensi untuk terjadinya hipertensi cukup esensial. Pada penggunaan obat hipertensi sebagian besar tidak mengonsumsi obat hipertensi (85\%). Hal ini disebabkan karena sebagian besar tidak mempunyai riwayat hipertensi. Pada kebiasaan minum alkohol, sebagian besar tidak mempunyai kebiasaan minum alkohol (78,3\%).
Demikian juga dengan kebiasaan merokok, sebagian besar responden penelitian tidak merokok $(75 \%)$. Pada kebiasaan merokok hasil penelitian menunjukkan tidak terdapat pengaruh bermakna dengan kejadian hipertensi. ${ }^{12}$ Pada kategori IMT diperoleh data bahwa terdapat 16 orang $(26,7 \%)$ dengan kategori gemuk dan 16 orang (26,7\%) dengan kategori obes I.

Karakteristik univariat variabel penelitian pada frekuensi makan ikan laut mendapatkan bahwa sebagian besar termasuk dalam kategori sedang dalam mengonsumsi ikan laut yakni 31 orang (51,7\%), dan kategori banyak yaitu 28 orang $(46,7 \%)$. Hal ini menunjukkan bahwa subyek penelitian lebih dominan mengonsumsi jenis ikan laut dari pada tidak mengonsumsi ikat laut. Pada karakteristik makan daging, sebagian besar kurang makan daging yakni 25 orang $(41,7 \%)$; sedang sebanyak 19 orang $(31,7 \%)$; dan kurang sebanyak 16 orang $(26,7 \%)$. Hal ini memperlihatkan bahwa frekuensi subyek mengonsumsi daging cukup banyak. Pola makan yang banyak mengandung lemak akan cenderung menyebabkan hipertensi. ${ }^{13}$

Analisis data menggunakan uji MannWhitney mendapatkan perbedaan TDS dan TDD antara daerah pedesaan dan daerah perkotaan. Hasil uji deskriptif menunjukkan bahwa nilai rerata TDS dan TDD di daerah rural lebih rendah dibandingkan dengan daerah urban. Data univariat tekanan darah dengan pola makan daging di daerah urban menunjukkan bahwa terdapat 11 orang $(36,7 \%)$ dengan pre-hipertensi dan 4 orang $(13,3)$ dengan hipertensi stage I dibandingkan dengan tekanan darah pada masyarakat di daerah pedesaan yang sebagian besar mempunyai tekanan darah normal yakni 24 orang (80\%).

Penelitian oleh Sulastri menyatakan bahwa pada masyarakat yang banyak makan ikan laut dengan kandungan asam lemak tidak jenuh, kandungan omega 3 pada ikan laut berhubungan langsung dengan kejadian hipertensi. Hasil penelitian lain juga menunjukkan bahwa kandungan asam lemak omega 3 mencegah kejadian penyakit-penyakit yang bersifat degene- 
ratif. Hal ini berlaku bagi jenis ikan laut yang dalam keadaan segar atau belum diawetkan dengan proses pengeringan dan pengasinan. Ikan yang sudah diasinkan banyak mengandung natrium yang akan meningkatkan kejadian hipertensi. ${ }^{13-15}$

Ikan merupakan makanan jenis lauk hewani yang sangat mudah dijangkau sesuai dengan kondisi perairan negeri Indonesia yang kaya akan hasil laut. Semua kalangan dapat dengan mudah mendapatkan hasil laut ini. Ikan merupakan makanan yang rendah kalori dan berprotein tinggi yang baik untuk otak. Semua manfaat tersebut berasal dari asam omega 3 lemak tak jenuh ganda, populer disebut sebagai omega 3, yang banyak terdapat dalam minyak ikan. Hubungan antara omega 3 dan kesehatan jantung yaitu bahwa ikan yang tinggi asam lemak sangat penting untuk kesehatan tubuh secara umum. Makan ikan laut hanya dua atau tiga kali dalam satu minggu cukup untuk menguntungkan bagi tubuh. Keuntungan mengonsumsi ikan dapat mencegah berbagai penyakit degeneratif seperti kasus hipertensi. ${ }^{16}$

Konsumsi makanan daging yang banyak mengandung lemak dapat menyebabkan hipertensi. Golongan daging yang banyak mengandung lemak ialah daging babi, sapi, dan ayam. Asupan jangka panjang dari daging dan unggas dikaitkan dengan peningkatan risiko hipertensi. Penelitian lain menunjukkan bahwa untuk mencegah penyakit kardiovaskular maka konsumsi daging merah harus dibatasi dan yang mengandung banyak asam lemak jenuh. ${ }^{17-20}$

Konsumsi daging berlebihan akan menyebabkan timbunan lemak dalam tubuh. Berdasarkan tabulasi silang antara subyek dengan kegemukan terdapat 6 orang (10\%) yang mengalami prehipertensi dan 4 orang $(6,7 \%)$ yang mengalami hipertensi stage I, sedangkan pada subyek dengan obesitas I yang mengalami pre-hipertensi sebanyak 5 orang $(8,3 \%)$, hipertensi stage I sebanyak 3 orang $(5 \%)$, dan hipertensi stage II sebanyak 1 orang $(1,7 \%)$. Hal ini menggambarkan bahwa orang dengan kegemukan maupun obesitas lebih cende- rung mengalami kasus hipertensi tipe ringan sampai berat. ${ }^{21}$

Penyandang hipertensi harus menyesuaikan gaya hidup mereka dan berhenti merokok, mengurangi konsumsi minuman beralkohol, mengendalikan berat badan, memperhatikan pola makan, seperti mengurangi konsumsi makanan yang asin, dan berolahraga secara teratur. Aktifitas badan baik bagi penyandang hipertensi. Faktor intake makanan yang mengandung lemak jenuh merupakan faktor risiko tinggi terhadap kejadian hipertensi.

Perbandingan proporsi kasus hipertensi antara masyarakat yang mengonsumsi ikan laut dengan daging terlihat jelas. Data menunjukkan bahwa masyarakat yang lebih banyak mengkonsumsi daging memiliki kecenderungan mengalami hipertensi lebih besar dibandingkan dengan masyarakat yang lebih banyak mengkonsumsi ikan laut. Hasil penelitian menunjukkan bahwa risiko penurunan hipertensi berhubungan dengan peningkatan konsumsi makanan laut. ${ }^{18}$ Proporsi masyarakat yang mengonsumsi ikan laut sebagian besar mempunyai tekanan darah normal yakni sebanyak $38,3 \%$, sedangkan proporsi masyakat yang banyak mengonsumsi daging terdapat $11,7 \%$ yang mengalami prehipertensi dan 8,3\% mengalami hipertensi stage I. Tidak terdapat hubungan antara konsumsi ikan laut dengan kejadian hipertensi, sebaliknya terdapat hubungan bermakna antara pola makan daging dengan kejadian hipertensi. Jika dihubungkan antara pola makan daging dengan IMT diperoleh bahwa subyek yang makan daging dalam jumlah banyak secara dominan menyandang kegemukan $(11,7 \%)$ dan obesitas I sebanyak $10 \%$. Sebaliknya pada masyara-kat yang kurang mengonsumsi daging IMT lebih banyak pada kategori normal yakni 15 orang $(25 \%)$. Hal ini menunjukkan bahwa terdapat hubungan antara perilaku konsumsi daging dengan IMT.

\section{SIMPULAN}

Berdasarkan hasil penelitian ini dapat disimpulkan bahwa terdapat perbedaan bermakna antara tekanan darah (sistol dan 
diastol) di daerah rural (daerah pedesaan) yang penduduknya lebih banyak makan ikan laut dengan tekanan darah di daerah urban (daerah perkotaan) yang penduduknya lebih banyak makan daging.

\section{SARAN}

Sehubungan dengan hal ini, perlu bagi masyarakat untuk dapat memanfaatkan bahan makanan yang bersumber dari produk ikan karena mengandung $\omega-3$ dan $\omega-6$ yang dapat menurunkan tekanan darah dan berbagai risiko kardiovaskuler disamping memenuhi kebutuhan protein tubuh.

Masyarakat harus membatasi konsumsi daging secara berlebihan dalam usaha pencegahan kasus hipertensi yang berdampak pada penyakit kardiovaskular.

\section{DAFTAR PUSTAKA}

1. World Health Organization (WHO). Surveilance of major non communicable disease in South East Asian Region. 2011.

2. Tjandra. Prevalensi penyakit hipertensi pada penduduk Indonesia. 2012. Available from: http://ejournal.litbang.depkes. go.id/index.php/hsr/article/view/ 1925/2684.

3. Kemkes RI. Badan Penelitian Dan Pengembangan Kesehatan. Available from: http://www.litbang.depkes.go.id/ sites/download/bukulaporan/lapnasrisked2013.pdf. 2013

4. Yulianti S, Maloedyn S. 30 Ramuan Penakluk Hipertensi. Jakarta: AgroMedia Pustaka, 2006.

5. Arif D, Rusnoto, Hartina D. Faktor-faktor yang berhubungan dengan kejadian hipertensi pada lansia di pusling Desa Klumpit UPT Puskesmas Gribig Kabupaten Kudus. JIKK. 2013;4:18-43.

6. Etherton PMK, Haris WS, Appel LJ. Omega-3 fatty acids and cardiovascular disease: New recommendation from the American Heart Association. Arterioscler, Thromb, Vasc Biol 2003; 23(2);151-2.

7. Wahlqvist ML. What 's so healthy about seafood - A guide for seafood marketers. Deakin: Fisheries Research and Develop-ment Corporation, 2004

8. Manikome S, Rompas S, Masi G. Gambaran konsumsi makanan laut penderita hipertensi di wilyah kerja Puskesmas Dagho Kecamatan Tamako. Jurnal Keperawatan. 2016;4(1).

9. Puspitasari DR, Setyabudi MT, Rohmani A. Hubungan usia, graviditas dan indeks massa tubuh dengan kejadian hipertensi dalam kehamilan. Jurnal Kedokteran Muhammadiyah. 2013;2(1):29-33.

10. Hermida RC, Ayala DE, Crespo JJ, Mojon A, Chavan L, Fontao MJ, Fernandez JR. Influence of age and hypertension treatment-time on ambulatory blood pressure in hypertensive patients. Chronobiol Int. 2013;30(1-2):176-91.

11. Pradetyawan. Hubungan usia dan jenis kelamin dengan tekanan darah tinggi di Posyandu Lansia Desa Triyagan Mojolaban Sukoharjo [Tesis]. Surakarta: Universitas Muhamadiyah; 2014.

12. Mulyani $Y$, Arifin $Z$, Marwansyah. Korelasi perilaku merokok dengan derajat hipertensi pada penderita hipertensi di puskesmas wilayah kerja Dinas Kesehatan Banjarbaru. Jurnal Skala Kesehatan. 2014; 5(2).

13. Andria KM. Hubungan antara perilaku olahraga, stress dan pola makan dengan tingkat hipertensi pada lanjut usia di posyandu lansia Kelurahan Gebang Putih Kecamatan Sukolilo Kota Surabaya. Jurnal Promkes. 2013;1(2).

14. Sulastri D. Hubungan Asupan dan kadar omega 3 plasma dengan kejadian hipertensi pada etnik Minangkabau di Kota Padang. Majalah Kedokteran Andalas. 2010; 34(2).

15. 15Purba RB, Paruntu O, Sahelangi O. Pemberian asam lemak tidak jenuh omega 3 terhadap penurunan kadar asam urat pada penderita asam urat (gout) pasien rawat jalan RSUP Prof. Dr. R. D. Kandou Manado. Gizido. 2016;5(1).

16. Windratie. Manfaat makan ikan: jantung sehat. sperma kuat. Artikel CNN Indonesia Rabu 28-01-2015. Available from:

https://www.cnnindonesia.com/.../manf aat-makan-ikan-jantung sehat.

17. Manawan A. Hubungan antara konsumsi makanan dengan kejadian hipertensi di Desa Tandengan Satu Kecamatan Eris Kabupaten Minahasa. Pharmacon. 2016;5(1). 
18. Borgi L, Curhan GC, Willett WC, Hu FB, Satija A, Forman JP. Long-term intake of animal flesh and risk of developing hypertension in three prospective cohort studies. J Hypertens. 2015;33(11):2231-8.

19. Oude Griep LM, Seferidi P, Stamler J, Van Horn L, Chan Q, Tzoulaki I, et al. Relation of unprocessed, processed red meat and poultry consumption to blood pressure in East Asian and Western Adults. J Hypertens. 2016; 34(9):1721-9.
20. Lidiyawati, Kartini, Apoina. Hubungan asupan asam lemak jenuh, asam lemak tidak jenuh dan natrium dengan kejadian hipertensi pada wanita menopause di Kelurahan Bojongsalaman [Tesis]. Semarang: Universitas Diponegoro; 2014.

21. Kapriana MT, Sulchan M. Asupan tinggi lemak dan aktivitas olahraga sebagai faktor risiko terjadinya hipertensi obesitik pada remaja awal [Tesis]. Semarang: Universitas Diponegoro; 2012. 